\title{
Changing opinions about research by Saudi medical students
}

This article was published in the following Dove Press journal:

Advances in Medical Education and Practice

13 October 2017

Number of times this article has been viewed

\section{Alberto Enrique D'Ottavio \\ Rosario Faculty of Medical Sciences, National Rosario University, Rosario, Argentina}

Correspondence: Alberto Enrique D'Ottavio

Rosario Faculty of Medical Sciences, National Rosario University, Rosario, Argentina

Email aedottavio@hotmail.com

\section{Dear editor}

After analyzing the appealing communication, "Changing opinions about research by Saudi medical students," authored by Ahmad Abulaban et al, I I would like to offer some complementary data on that issue rooted in the 25 years experience carried out in our medical school and related to an extracurricular and voluntary program of scientific formation in medical sciences for undergraduates. In this regard, previous considerations and results ${ }^{2,3}$ are updated and summarized. During that time period, 614 undergraduate students (400 women and 214 men) were admitted to that program as initiation fellows, 471 of them also fulfilling the subsequent advanced phase. Consequently, $76 \%$ of the students completed the biennial challenge. Three quarters of the research projects accepted and assessed during the 25-year period focused on biological aspects while the remaining ones were centered in educational and psycho-social features. While a total predominance of medical students was evidenced until 2004, nursing and speech therapy students increased from 2005 onward. Between 1991 and 2016, the quantitative achievements of the program were as follows: participation in 1957 communications in scientific meetings and collaboration in 267 and 200 papers published in national and international journals, respectively. Similarly, indirect contributions to $55 \mathrm{PhD}$ theses were recorded. Qualitatively, the main competences acquired after carrying out both the stages were, as formerly reported, satisfactory literature search, critical reading of scientific papers, planning of research activities, feasibility, quality and pertinence of the projects, training with different procedures, data registration as well as proper wording of progress and final reports, abstracts, short communications, and full-length papers, among others. ${ }^{2}$ Moreover, a poll systematically applied after finishing both the stages revealed $95 \%$ of positive results related to the acquired competences and the resulting outcomes. The simultaneous creation and development of the Scientific Association of Medical Students strengthened its advantages and generated a fruitful interaction between this institution and the program under consideration. To sum up, research training in undergraduates becomes an advisable practice for their future professional and quotidian life.

\section{Disclosure}

The author reports no conflicts of interest in this communication. 


\section{References}

1. Abulaban A, Alharbi A, BinDajam O, et al. Changing opinions about research by Saudi medical students. Adv Med Educ Pract. 2017;2017(8):571-575.

2. Montenegro SM, Tarrés MC, D’Ottavio AE. Entrenamiento científico en el grado de ciencias médicas; descripción, análisis y crítica de una experiencia innovadora en Argentina. Rev Arg Educ Med. 2007;1(1):17-22.

3. Gayol MC, Montenegro SM, Tarrés MC, D’Ottavio AE. Competencias investigativas. Su desarrollo en carreras del Área de la Salud. Revista Uni-Pluri/Versidad. 2008;8(2):47-52.

Dove Medical Press encourages responsible, free and frank academic debate. The content of the Advances in Medical Education and Practice 'letters to the editor' section does not necessarily represent the views of Dove Medical Press, its officers, agents, employees, related entities or the Advances in Medical Education and Practice editors. While all reasonable steps have been taken to confirm the content of each letter, Dove Medical Press accepts no liability in respect of the content of any letter, nor is it responsible for the content and accuracy of any letter to the editor.

Advances in Medical Education and Practice

Dovepress

\section{Publish your work in this journal}

Advances in Medical Education and Practice is an international, peerreviewed, open access journal that aims to present and publish research on Medical Education covering medical, dental, nursing and allied health care professional education. The journal covers undergraduate education, postgraduate training and continuing medical education including emerging trends and innovative models linking education, research, and health care services. The manuscript management system is completely online and includes a very quick and fair peer-review system. Visit http://www.dovepress.com/testimonials.php to read real quotes from published authors.

Submit your manuscript here: http://www.dovepress.com/advances-in-medical-education-and-practice-journal 